\title{
THE IMPACT OF THE LOW THROW FAULT ON THE STABILITY OF ROADWAYS IN A HARD COAL MINE
}

\author{
PIOTR MAŁKOWSKI \\ AGH University of Science and Technology, Faculty of Mining and Geoengineering, \\ al. Mickiewicza 30,30-059 Kraków, Poland, tel: +48 1261721 04, e-mail: malkgeom@agh.edu.pl
}

\section{ŁUKASZ OSTROWSKI}

AGH University of Science and Technology, Faculty of Mining and Geoengineering, al. Mickiewicza 30, 30-059 Kraków, Poland

\section{PIOTR BACHANEK}

Uran Sp. z o.o. Przedsiębiorstwo Techniczno-Wdrożeniowe, ul. Krasińskiego 29, 40-019 Katowice, Poland

\begin{abstract}
Ensuring roadways stability in hard coal mines is one of the main challenges faced by engineers. A changeable geological structure have caused the roadway's conditions to vary, thus influencing its stability. One of the causes of those changes is the presence of a previously undiscovered fault zone (small faults crossed the roadway) within which a significant convergence or support deformation may occur.

The paper presents the impact of low throw faults on the degree of convergence of roadways. Convergence is determined for two roadways in the hard coal mine. A special measuring stations have been installed in one of the roadways, and they have carried out constant measurements for 15 months. In the other roadway, the degree of convergence has been determined on the basis of an on-site verification and comparison of the measurements obtained and the initial values, based on the roadway's records.

On the basis of the obtained convergence results, the impact of a single fault and the entire fault zone on the roadway stability has been determined. The impact of a single, low throw fault results in a $30 \%$ higher vertical convergence than in the case of roadways free of geological disturbance. In the roadway section located in the fault zone, vertical convergence is 4 times higher than in the case of sections free of disturbance impact. The floor heaving constitutes ca. $90 \%$ of vertical convergence both for roadway sections situated within the faulted zones and for sections free of the influence of any additional factors.
\end{abstract}

Key words: fault, roadway stability, roadway convergence, floor heaving

\section{INTRODUCTION}

Hard coal mines in Poland maintain thousands of kilometers of new roadways, additionally carrying out hundreds of new development workings each year; therefore ensuring their stability is one of the main challenges faced by engineers.

A changeable geological structure of the Upper Silesian Coal Basin [USCB] and its exploitation history have caused the conditions of roadway sections to vary, thus influencing their stability. One of the causes of those changes is the presence of a previously un- discovered fault zone, within which a significant convergence or support deformation, or even its destruction, may occur [7], [17], [18]. During mining research conducted in the USCB, experts [10, [14], [15] emphasized the significant impact of a single fault and of a fault zone on the maintenance of the roadway as one on the main factors influencing its stability.

In areas with a considerable degree of tectonic engagement, the phenomenon of occurrence of small faults on the roadway length is very often encountered, including the area of Monoklina Zofiówki and adjacent areas. 
The paper presents the impact of low throw faults on the degree of convergence of roadways. The convergence has been determined for two roadways in the KWK "Borynia-Zofiówka-Jastrzębie" mine. Special measuring stations have been installed in one of the roadways, and they have carried out constant measurements for 15 months. In the other roadway, the degree of convergence has been determined on the basis of an on-site verification and comparison of the measurements obtained and the initial values, based on the roadway records.

\section{IMPACT OF LOW THROW FAULTS ON THE STABILITY OF ROADWAYS}

In hard coal mines, faults tend to occur in close vicinity to one another, forming so-called fault zones. They are characterized by the occurrence of several, usually non-parallel fault surfaces, along which displacement of rock layers occurred. The occurrence of numerous small faults may be related to tectogenesis [5], [9] of the analyzed area and the degree of restructuring and diagenesis of rocks present in this area [1]. Moreover, it has been observed that the coal seams with a higher content of naturally accumulated mineral substance are characterized by a higher resistance to the influence of tectonic processes [3]. Low throw faults are often coal seam faults that, according to Kidybiński [5], are characterized by a throw of up to ca. $2 \mathrm{~m}$. On the other hand, Nieć [9] claims that the throw of small faults does not exceed the height of development workings.

It should be noted that each fault causes the occurrence of a local rock weakening whose range depends on the rock hardness, the degree of its tectonic engagement and the extent of the fault throw [5]. The size of this zone was subject to numerous studies. Wojnar has established a $1 \mathrm{~m}$ zone of significant drop in the rock resistance for faults with 2-7 $\mathrm{m}$ throws, and the overall range of the rock weakening zone was $5 \mathrm{~m}$ on both sides of the fault surface [5]. Similar observations were presented by Nieć [9], who demonstrated a drop in uniaxial compressive strength of sandstone by more than a half, on a $0-4 \mathrm{~m}$ section for the Kłodnicki fault with a $5 \mathrm{~m}$ throw and a $0-5$ section for the Bytom fault with a $12 \mathrm{~m}$ throw. Zorychta [23] indicated the empirical dependence between the determination of a fault zone $\left(L_{u}\right)$, vertical height of the fault throw $\left(h_{u}\right)$ and the lean angle of the fault surface $\left(\beta_{u}\right)$ (formula (1))

$$
L_{u}=\frac{2.5 \times \sqrt{h_{u}}}{\sin \beta_{u}} .
$$

Meanwhile, other sources [8] indicate that the impact of the fault on the roadway stability should be taken into account in the distance of three times the height of the throw on each side of the fault surface and the displacements could be there over 4 times higher than in undisturbed areas [4]. Shen's research team [16], in their numerical calculations, indicate the range of impact of the fault on the weakening of rocks as a value two to four times higher than the throw height of that fault. According to Bukowska and Ćmiel [1], such a marked drop in the rock strength in the immediate vicinity of the fault surface is typical of extensive rock destruction zones. Their impact range is often relatively small for a given section of the roadway, but it may result in a significant deterioration of the roadway functionality or its complete loss. Research clearly shows the proportional increase in rock strength to the distance from the fault surface [5], [9], [23].

The Yao team [22], during its research, have determined a minimum height of fault throw influencing the roadway stability on a $2 \mathrm{~m}$ level. If the fault throw is higher than $2 \mathrm{~m}$, the roadway should be designed and secured similarly to undisturbed areas - without taking into account the impact of the fault, as the stress variations in the rock mass around the roadway are insignificant and the rocks are intact [22]. However, it should be noted that this research was conducted in conditions that are entirely different than those in the USCB.

A decrease in rock strength parameters around the roadway results in a larger destruction zone and a higher load to the frame support, described in "Zasady projektowania obudowy wyrobisk korytarzowych..." (Principles of ground support designing for roadways...) [21], [23]. Those guidelines for roadways located in a fault zone impose that $20 \%$ higher frame support loads should be taken into account, as well as a reduction in rock strength in that zone by an empirical coefficient, which, as a consequence, significantly influences the convergence of the roadway.

\section{D-2 MAINGATE STABILITY ANALYSIS}

The measurement of roadway convergence allows for a quantitative assessment of its stability. 
The most considerable displacements on the roadway contour occur in a relatively short time (considering the exploitation period) after its drivage. Significant displacements may occur within up to 90 days [2], and for the USCB conditions, within 200-220 days from roadway drivage [6]. Sometimes, even after 4 years the roadway driving had been completed, secondary balance equilibrium does not occur [10]. However, according to research conducted by the AGH [6], in the period of up to 3 months from roadway drivage, a fracture zone is fully developed above the roadway, statically influencing the roadway support. This phenomenon has significant consequences on the secondary balance equilibrium of the rock mass, and, as a result, on the rock mass displacements.

\subsection{RESEARCH AREA}

The D-2 maingate is situated on the average depth of 1000 meters. The roadway rib is composed of a coal seam of a total thickness of $4.1 \mathrm{~m}$. The inclination of the seam does not exceed a few degrees [19].

The immediate roof of the roadway is characterized by uniaxial compressive strength of $57 \mathrm{MPa}$. It is composed of coal-bearing shales with mudstone interlayers. The strength of a coal-bearing shale is $33.8 \mathrm{MPa}$. In higher strata, a monolithic layer of sandstone of $8.5 \mathrm{~m}$ with $R_{c}=80.8 \mathrm{MPa}$ is located. The immediate floor of the roadway is composed of claystone with single coal laminas with $R_{c}=50.3 \mathrm{MPa}$.

In the analyzed section, the roadway was made in the $\mathrm{LP} 12 / 4 / \mathrm{V} 32$ steel yielding support (roadway height:
$4.225 \mathrm{~m}$, roadway width near the floor: $6.10 \mathrm{~m}$ ) with $0.6 \mathrm{~m}$ spacing. To stabilize the steel frames, tubular stretchers have been applied; their length has been adjusted to the frame support spacing. The welded mining mesh with knots was applied in the roadway as a lining [19].

\subsection{RESEARCH METHOD}

In order to determine roadway convergence, and subsequently, its stability, in situ measurements were carried out. They were commenced in April 2015 and continued until July 2016 during everyday exploitation of the roadway. All the measured values were compared with nominal measurements of the roadway.

Seven measurement bases were installed in the roadway, each placed within the $25 \mathrm{~m}$ distance from the other. Roadway convergence was measured on each measurement base containing four measurement points - PP1, PP2, PP3, PP4 (Fig. 1), carried out on the basis of three different measurements including: change of the roadway height $H$, change of the roadway width $S$ and the change of floor heaving value $u_{s p}$ (Fig. 1).

In relation to the subject of this paper, results from three measurement bases were presented (Fig. 2). Namely: base 930 (roadway without the impact of additional mining and geological factors), base $790 \mathrm{~m}$ (fault with a $0.7 \mathrm{~m}$ throw and the impact zone of the exploitation edge of the 409/3 seam) and base $757 \mathrm{~m}$ (a series of low throw faults from 0.4 to $3.2 \mathrm{~m}$, creating a series of faults along the length of $12 \mathrm{~m}$ ).

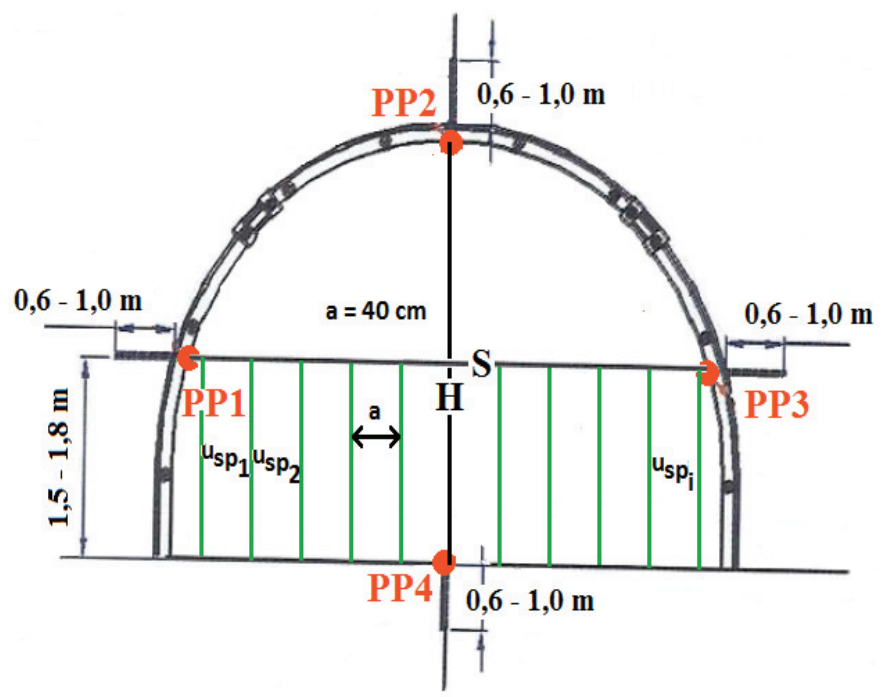

Fig. 1. Scheme of measurement base and the measurement methodology in D-2 maingate 


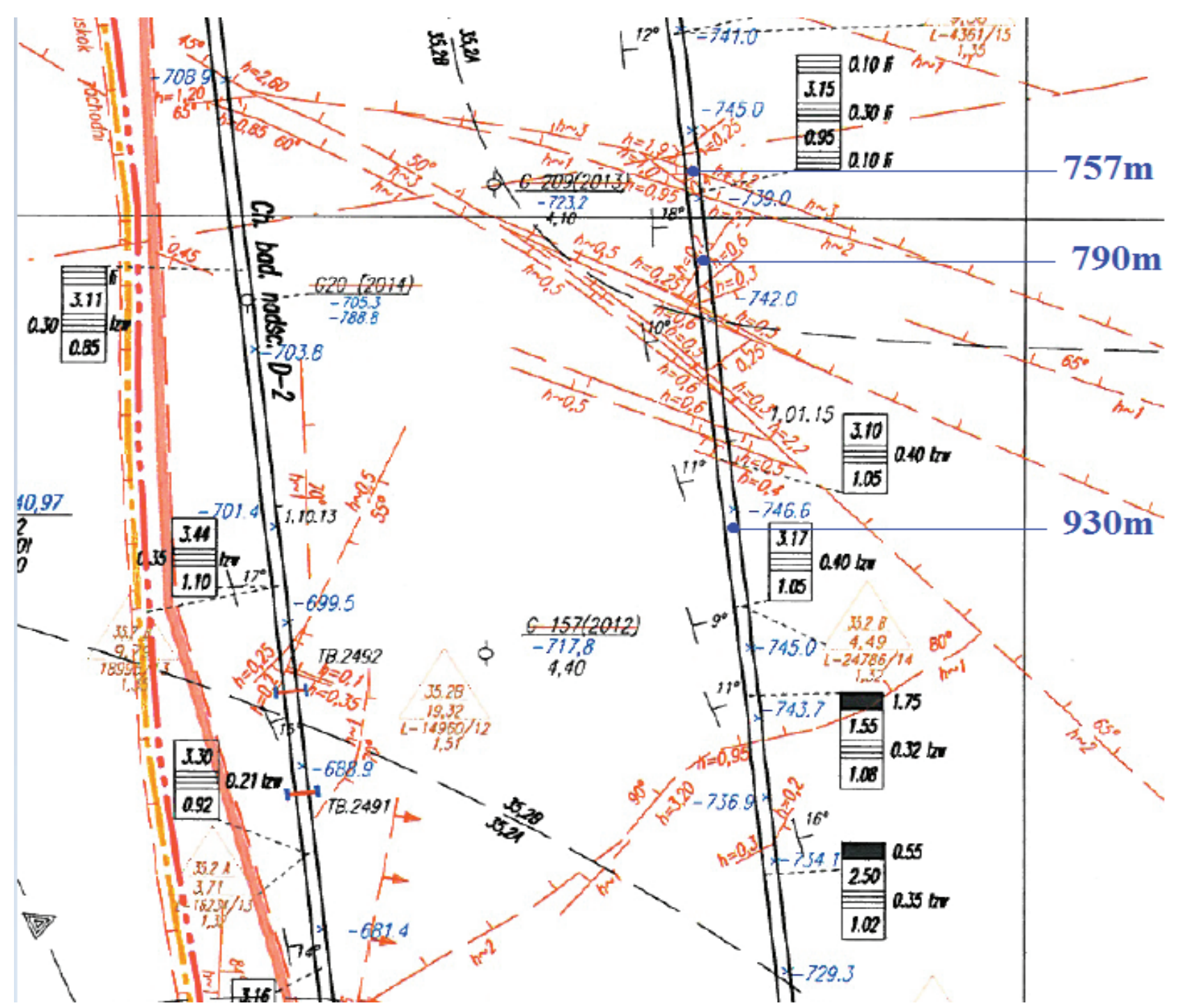

Fig. 2. The mining map of 403/1 seam with analyzed D-2 maingate and measurement bases

\subsection{ASSESSMENT OF STABILITY OF THE D-2 MAINGATE \\ ON THE BASIS OF THE ROADWAY DESIGN EFFICIENCY INDEX}

In order to assess the initial conditions of roadway maintenance, the Roadway Design Efficiency Index $R D E$ was established. Detailed classification is presented in the paper written by its authors [8]. Points were assigned based on the technical and geological records for the analyzed roadway sections [19].

The most favorable mining and geological conditions occur at $930 \mathrm{~m}$ of the roadway (acc. to the longwall advance). The roadway in this section, in comparison to other measurement bases, is not subject to additional mining and geological factors, e.g., fault or flooding. On the next base $(790 \mathrm{~m})$, there is a fault with a $0.7 \mathrm{~m}$ throw; it is also an impact zone of the overlaying exploitation edge of the 409/3 seam, situated within the distance of $97-115 \mathrm{~m}$. In spite of occurrence of additional mining and geological factors, conditions in this roadway section, similarly to those existing at $930 \mathrm{~m}$, have been classified as favorable (class II). The situation changes at $757 \mathrm{~m}$, with a series of five low throw faults and different alignments when compared to the roadway position, creating a so-called fault zone the length of $12 \mathrm{~m}$. One of the faults, with a $3.2 \mathrm{~m}$ throw, was observed also in the overlaying 410 seam. Other faults have the following throws: $0.4 \mathrm{~m}, 0.5 \mathrm{~m}, 0.95 \mathrm{~m}$ and $1.0 \mathrm{~m}$, respectively [19]. Conditions of roadway maintenance in this section have been classified as average (class III). Results of maintenance capability assessment for the D-2 maingate are shown in Table 1. 
Table 1. The assesment of the D-2 maingate maintenance ego D-2, using RDE index, acc. to [8]

\begin{tabular}{|c|c|c|c|c|}
\hline \multicolumn{2}{|c|}{ Measurement base } & $930 \mathrm{~m}$ & $790 \mathrm{~m}$ & $757 \mathrm{~m}$ \\
\hline \multicolumn{2}{|c|}{ Geological disturbance } & - & fault $0.7 \mathrm{~m}$ & fault $3.2 \mathrm{~m}$ \\
\hline \multirow{3}{*}{ Factors } & Natural & 87.92 & 82.94 & 71.06 \\
\hline & Geomechanical & 49.88 & 49.88 & 42.46 \\
\hline & Mining & 93.26 & 93.26 & 93.26 \\
\hline \multicolumn{2}{|c|}{ Total RDE } & 230.2 & 225.22 & 206.72 \\
\hline \multicolumn{2}{|c|}{ Roadway Design Efficiency class } & II & II & III \\
\hline \multicolumn{2}{|c|}{$\begin{array}{l}\text { Description of the maintenance } \\
\text { conditions }\end{array}$} & $\begin{array}{l}\text { Favourable } \\
(221-260)\end{array}$ & $\begin{array}{l}\text { Favourable } \\
(221-260)\end{array}$ & $\begin{array}{c}\text { Fair } \\
-220) \\
\end{array}$ \\
\hline
\end{tabular}

\section{RESULTS OF THE ROADWAY CONVERGENCE ASSESSMENT}

\subsection{MEASUREMENT BASE OUTSIDE OF THE GEOLOGICAL DISTURBANCE ZONE}

Convergence measurements in the measurement base located at $930 \mathrm{~m}$ of the D-2 maingate, located outside geological disturbance zones, have been carried out for 270 days. During this period, low values of roadway convergence have been noted. They were, respectively: roadway width change $\left(\Delta S_{w}\right)$ $-20 \mathrm{~cm}$, roadway height change in the opening $\left(\Delta h_{w}\right)$ $-38.5 \mathrm{~cm}$, average floor heaving $\left(u_{s p}\right)-25.8 \mathrm{~cm}$, and the cross section change $\left(\Delta P_{w}\right)-2.87 \mathrm{~m}^{2}$. The dynamics of those changes is shown in Fig. 3, and the values obtained are presented in Table 2. After ca. 600 days from roadway drivage, its height was $384 \mathrm{~cm}$, which constituted ca. $91 \%$ of the nominal height of the opening. The width of the roadway, in July 2016, constituted $96.7 \%$ of the nominal width $S$, which was $610 \mathrm{~cm}$.

Table 2. Maingate D-2 convergence - base on $930 \mathrm{~m}$

\begin{tabular}{|c|c|c|c|c|c|c|c|c|c|}
\hline $\begin{array}{c}\text { Date of } \\
\text { measure- } \\
\text { ment }\end{array}$ & \multicolumn{2}{|c|}{$\begin{array}{c}\text { Width } \\
\text { change }\end{array}$} & \multicolumn{2}{c|}{$\begin{array}{c}\text { Height } \\
\text { change }\end{array}$} & \multicolumn{3}{c|}{$\begin{array}{c}\text { Floor } \\
\text { heaving }\end{array}$} & \multicolumn{2}{c|}{$\begin{array}{c}\text { Cross- } \\
\text {-section } \\
\text { change }\end{array}$} \\
\cline { 2 - 12 } & $\begin{array}{c}\Delta S_{w} \\
{[\mathrm{~cm}]}\end{array}$ & $\begin{array}{c}\Delta S_{w} \\
{[\%]}\end{array}$ & $\begin{array}{c}\Delta h_{w} \\
{[\mathrm{~cm}]}\end{array}$ & $\begin{array}{c}\Delta h_{w} \\
{[\%]}\end{array}$ & $\begin{array}{c}u_{s p \min } \\
{[\mathrm{cm}]}\end{array}$ & $\begin{array}{c}u_{s p \max } \\
{[\mathrm{cm}]}\end{array}$ & $\begin{array}{c}u_{s p} \text { avg } \\
{[\mathrm{cm}]}\end{array}$ & $\begin{array}{c}\Delta P_{w} \\
{\left[\mathrm{~m}^{2}\right]}\end{array}$ & $\begin{array}{c}\Delta P_{w} \\
{[\%]}\end{array}$ \\
\hline 10.2015 & 14 & 2.3 & 32.5 & 7.7 & 2.7 & 28.1 & 15.1 & 1.86 & 8.6 \\
\hline 11.2015 & 14 & 2.3 & 32.5 & 7.7 & 3.7 & 28.1 & 16.1 & 1.92 & 8.9 \\
\hline 12.2015 & 16 & 2.6 & 34.5 & 8.2 & 4.7 & 31.2 & 17.8 & 2.20 & 10.2 \\
\hline 01.2016 & 17 & 2.8 & 35.5 & 8.4 & 4.9 & 31.5 & 19 & 2.35 & 10.9 \\
\hline 03.2016 & 19 & 3.1 & 37.5 & 8.9 & 5.7 & 33.1 & 21.8 & 2.48 & 11.5 \\
\hline 04.2016 & 19 & 3.1 & 38.5 & 9.1 & 5.7 & 34.3 & 24.4 & 2.66 & 12.4 \\
\hline 06.2016 & 19 & 3.1 & 38.5 & 9.1 & 5.7 & 35.1 & 25.3 & 2.81 & 13.1 \\
\hline 07.2016 & 20 & 3.3 & 38.5 & 9.1 & 5.7 & 35.1 & 25.8 & 2.87 & 13.3 \\
\hline
\end{tabular}

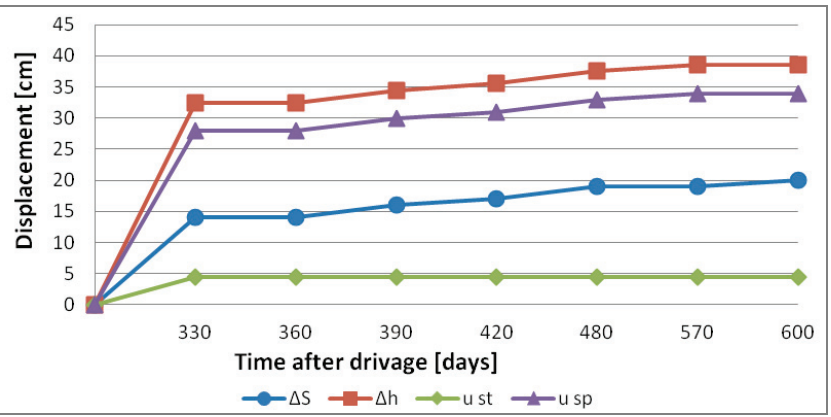

Fig. 3. Maingate D-2 convergence - base on $930 \mathrm{~m}$ ( $\Delta S$ - roadway width change, $\Delta h$ - roadway height change, $u_{s t}-$ roof displacement, $u_{s p}$-floor heaving)

\subsection{MEASUREMENT BASE LOCATED IN THE AREA OF A SINGLE FAULT}

The measurement base in the fault area was installed at $790 \mathrm{~m}$ of the D-2 maingate. The roadway support, in this area, was additionally reinforced with a V29 steel beams. Research conducted in this base lasted 16 months; 13 measurements were taken. Results are shown in Table 3. During 450 days of observations, the width of the roadway was reduced by $41 \mathrm{~cm}$, which constitutes around $7 \%$ of the original width. The roadway height, in the cross-sectional area of working, as a result of the influence of a single fault, was reduced by $12 \%(52 \mathrm{~cm})$. Reduction of both the width and the height of the roadway in the impact zone of the fault caused the roadway cross section to decrease. As a result of steel yielding support convergence, the cross section of the roadway, after 600 days from drivage in the above-mentioned area, was at $17.5 \mathrm{~m}^{2}$ (ca. $81 \%$ of the original value), which caused the ventilation conditions and the roadway functionality to deteriorate. Floor heaving, compared to the $930 \mathrm{~m}$ base located on the section free of geological disturbance, technically rose 1.5 times (Table 3) on its entire width. The average value of 
Table 3. Maingate D-2 convergence - base on $790 \mathrm{~m}$

\begin{tabular}{|c|c|c|c|c|c|c|c|c|c|}
\hline \multirow{2}{*}{$\begin{array}{c}\text { Date of } \\
\text { measurement }\end{array}$} & \multicolumn{2}{|c|}{ Width change } & \multicolumn{2}{|c|}{ Height change } & \multicolumn{3}{|c|}{ Floor heaving } & \multicolumn{2}{c|}{ Cross-section change } \\
\cline { 2 - 11 } & $\begin{array}{c}\Delta S_{w} \\
{[\mathrm{~cm}]}\end{array}$ & $\begin{array}{c}\Delta S_{w} \\
{[\%]}\end{array}$ & $\begin{array}{c}\Delta h_{w} \\
{[\mathrm{~cm}]}\end{array}$ & $\begin{array}{c}\Delta h_{w} \\
{[\%]}\end{array}$ & $\begin{array}{c}u_{s p \min } \\
{[\mathrm{cm}]}\end{array}$ & $\begin{array}{c}u_{s p \max } \\
{[\mathrm{cm}]}\end{array}$ & \begin{tabular}{c}
$u_{s p \text { avg }}[\mathrm{cm}]$ \\
\hline $\begin{array}{c}{\left[\% P_{w}\right.} \\
{\left[\mathrm{m}^{2}\right]}\end{array}$
\end{tabular} & $\begin{array}{c}\Delta P_{w} \\
{[\%]}\end{array}$ \\
\hline 04.2015 & 10 & 1.6 & 21.5 & 5.1 & 0.0 & 20.3 & 11.0 & 1.28 & 5.9 \\
\hline 05.2015 & 15 & 2.5 & 23.5 & 5.6 & 0.8 & 22.7 & 11.7 & 1.65 & 7.7 \\
\hline 06.2015 & 17 & 2.8 & 26.5 & 6.3 & 2.7 & 22.7 & 12.8 & 1.86 & 8.6 \\
\hline 08.2015 & 22 & 3.6 & 29.5 & 7.0 & 5.7 & 28.7 & 16.3 & 2.15 & 10.0 \\
\hline 09.2015 & 28 & 4.6 & 33.5 & 7.9 & 6.7 & 34.7 & 19.3 & 2.51 & 11.7 \\
\hline 10.2015 & 29 & 4.8 & 37.5 & 8.9 & 8.7 & 36.7 & 21.2 & 2.65 & 12.3 \\
\hline 11.2015 & 32 & 5.2 & 42.5 & 10.1 & 11.3 & 40.6 & 24.2 & 2.95 & 13.7 \\
\hline 12.2015 & 32 & 5.2 & 43.5 & 10.3 & 11.3 & 42.6 & 25.7 & 3.17 & 14.7 \\
\hline 01.2016 & 34 & 5.6 & 45.5 & 10.8 & 12.3 & 43.6 & 27.7 & 3.29 & 15.3 \\
\hline 03.2016 & 34 & 5.6 & 45.5 & 10.8 & 13.3 & 43.6 & 29.4 & 3.47 & 16.1 \\
\hline 04.2016 & 35 & 5.7 & 49.5 & 11.7 & 14.3 & 44.6 & 30.9 & 3.65 & 17.0 \\
\hline 06.2016 & 36 & 5.9 & 49.5 & 11.7 & 15.7 & 44.6 & 33.0 & 3.80 & 17.7 \\
\hline 07.2016 & 41 & 6.7 & 51.5 & 12.2 & 17.7 & 45.7 & 34.1 & 4.04 & 18.8 \\
\hline
\end{tabular}

floor heaving is $34 \mathrm{~cm}$. The rate of those changes is presented in Fig. 4.

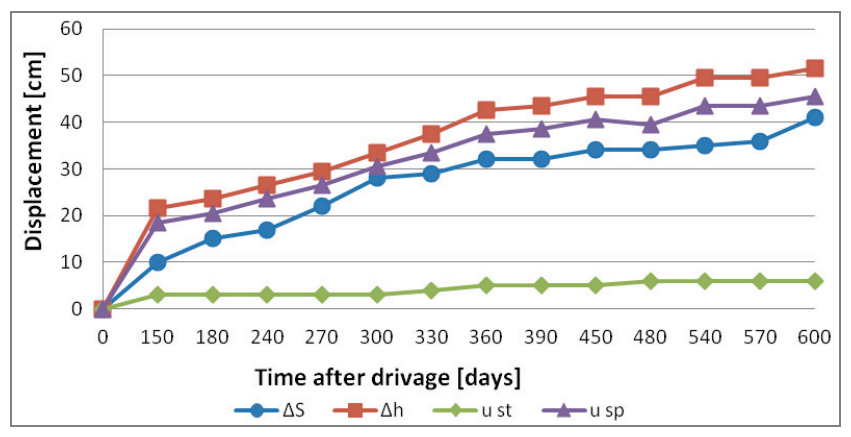

Fig. 4. Maingate D-2 convergence - base on $790 \mathrm{~m}$ ( $\Delta S$ - roadway width change, $\Delta h$ - roadway height change, $u_{s t}$ - roof displacement, $u_{s p}$-floor heaving)

\subsection{BASE LOCATED IN THE FAULT ZONE}

Studies conducted in the fault zone lasted 16 months; 11 measurements were taken. During 450 days of observations, the biggest dimension change has been obtained (Table 4). The drivage of the D-2 maingate in the fault zone has caused its $71 \mathrm{~cm}$ horizontal convergence, which is around $12 \%$ of the nominal width of the roadway. The weakening of rocks and extensive stress in the fault zone have considerably influenced the vertical convergence of the roadway. Roadway height, since its drivage, has decreased by ca. $170 \mathrm{~cm}$, which resulted in additional works that would ensure stability of the roadway - floor brushing has been carried out three times; its values were

Table 4. Maingate D-2 convergence - base on $757 \mathrm{~m}$

\begin{tabular}{|c|c|c|c|c|c|c|c|c|c|}
\hline \multirow{2}{*}{$\begin{array}{c}\text { Date of } \\
\text { measurement }\end{array}$} & \multicolumn{2}{|c|}{ Width change } & \multicolumn{2}{|c|}{ Height change } & \multicolumn{3}{|c|}{ Floor heaving } & \multicolumn{2}{c|}{ Cross-section change } \\
\cline { 2 - 11 } & $\begin{array}{c}\Delta S_{w} \\
{[\mathrm{~cm}]}\end{array}$ & $\begin{array}{c}\Delta S_{w} \\
{[\%]}\end{array}$ & $\begin{array}{c}\Delta h_{w} \\
{[\mathrm{~cm}]}\end{array}$ & $\begin{array}{c}\Delta h_{w} \\
{[\%]}\end{array}$ & $\begin{array}{c}u_{s p \min } \\
{[\mathrm{cm}]}\end{array}$ & $\begin{array}{c}u_{s p \max } \\
{[\mathrm{cm}]}\end{array}$ & $\begin{array}{c}u_{s p \text { avg }} \\
{[\mathrm{cm}]}\end{array}$ & $\begin{array}{c}\Delta P_{w} \\
{\left[\mathrm{~m}^{2}\right]}\end{array}$ & $\begin{array}{c}\Delta P_{w} \\
{[\%]}\end{array}$ \\
\hline 04.2015 & 28 & 4.6 & 16.5 & 3.9 & 0.4 & 77.2 & 43.9 & 4.28 & 19.9 \\
\hline 05.2015 & - & - & - & - & - & - & - & - & - \\
\hline $06.2015^{*}$ & 31 & 5.1 & 60.5 & 14.3 & 27.2 & 89.3 & 69.6 & 5.47 & 25.4 \\
\hline 08.2015 & 43 & 7.0 & 64.5 & 15.3 & 42.2 & 93.61 & 76.4 & 6.28 & 29.2 \\
\hline 09.2015 & - & - & - & - & - & - & - & - & - \\
\hline $10.2015^{* *}$ & 52 & 8.5 & 74.5 & 17.6 & 58.2 & 101.61 & 84.6 & 7.11 & 33.0 \\
\hline 11.2015 & 55 & 9.0 & 117.5 & 27.8 & 77.8 & 130.5 & 108.2 & 8.89 & 41.3 \\
\hline 12.2015 & 59 & 9.7 & 136.5 & 32.3 & 87.8 & 137.5 & 116.7 & 9.55 & 44.4 \\
\hline $01.2016^{* * *}$ & 64 & 10.5 & 138.5 & 32.8 & 89.8 & 141.5 & 118.3 & 9.69 & 45.0 \\
\hline 03.2016 & 65 & 10.7 & 145.5 & 34.4 & 96 & 146.5 & 122.5 & 9.97 & 46.3 \\
\hline 04.2016 & 67 & 11.0 & 145.5 & 34.4 & 103 & 148.5 & 126.5 & 10.22 & 47.5 \\
\hline 06.2016 & 70 & 11.5 & 149.5 & 35.4 & 111 & 161.61 & 137.4 & 10.80 & 50.2 \\
\hline 07.2016 & 73 & 12.0 & 167.5 & 39.6 & 118 & 180.5 & 148.1 & 11.67 & 54.2 \\
\hline
\end{tabular}

* - floor brushing ca. $70 \mathrm{~cm}$;* - floor brushing ca. $80 \mathrm{~cm}$; ** - floor brushing ca. $60 \mathrm{~cm}$. 
taken into account in the results obtained. Thus, total average floor heaving for the roadway located in the fault zone would be $150 \mathrm{~cm}$. If rocks had not been brushed from the floor, the roadway cross section would have been at as little as $45 \%$ of its original value, which means almost complete loss of the roadway functionality.

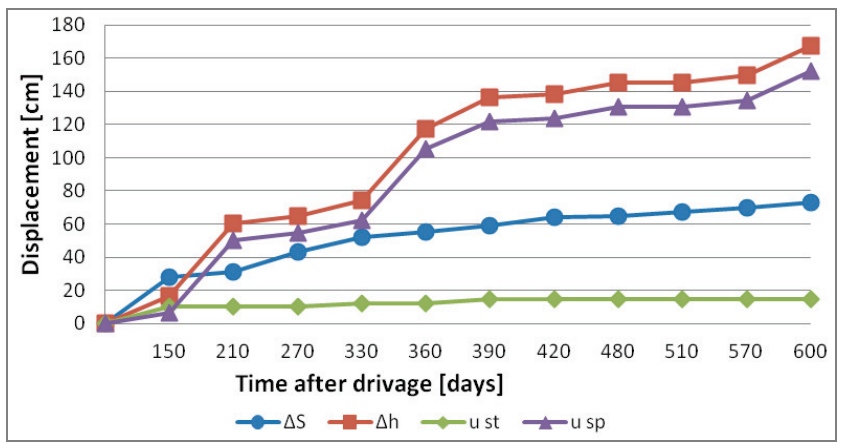

Fig. 5. Maingate D-2 convergence - base on $757 \mathrm{~m}$ ( $\Delta S$ - roadway width change, $\Delta h$ - roadway height change, $u_{s t}-$ roof displacement, $u_{s p}-$ floor heaving)

\subsection{SUMMARY OF MINING MEASUREMENTS IN THE D-2 MAINGATE}

On the basis of mining research conducted during a long period (450 days), it may be observed that vertical convergence has the strongest influence on relocation in the vicinity of the roadway. Floor heaving constitutes around $90 \%$ of vertical convergence, both for bases located in fault zones and for the base located outside that zone, which was also proved in other studies [11]-[13]. The value of roadway roof lowering, in each case, is from a few to around a dozen centimeters. For the base installed under the impact zone of a single fault or a fault zone, the vertical convergence does not exceed $40 \mathrm{~cm}$. For the base located at the 0.7 fault, the value of vertical convergence is ca. $52 \mathrm{~cm}-30 \%$ higher than at the base outside the impact zone of the fault. Vertical convergence occurs evenly, almost linearly. Meanwhile, the roadway located in the fault zone is characterized by an increase in vertical convergence that is close to linear, but with a lower correlation coefficient. The value is ca. $167.5 \mathrm{~cm}$ and is more than 4 times higher than in the case of roadway section free of the impact of the fault. A comparison of cross section sizes of roadways in different sections is shown in Fig. 6.

A comparison of the results of vertical convergence measurements is presented in the chart in Fig. 7. Although the roadway in the area of measurement bases located at $930 \mathrm{~m}$ and $790 \mathrm{~m}$ sections may be considered stable, the D-2 maingate located in the fault zone at $757 \mathrm{~m}$ loses its stability. It is also worth mentioning that, after each floor brushing, a periodic relaxation occurs, and the increase rate of deformations slows down for 150-200 days (Fig. 7).

A comparison of cross section sizes of roadways in different sections is shown in Fig. 6.

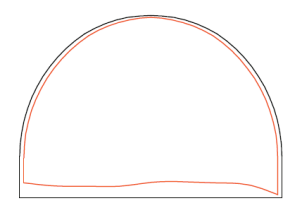

(a)

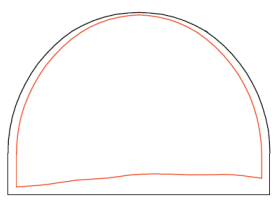

(b)

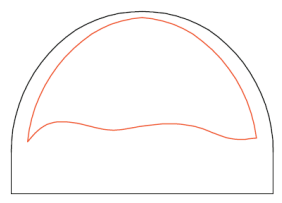

(c)
Fig. 6. Maingate D-2 convergence: (a) base on $930 \mathrm{~m}$, (b) base on $790 \mathrm{~m}$, (c) base on $757 \mathrm{~m}$

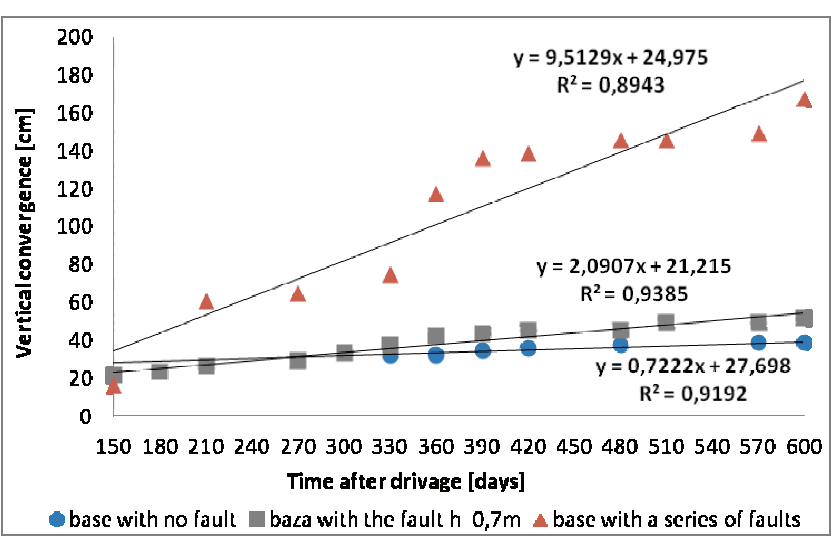

Fig. 7. Vertical convergence for the measurement bases

\section{INVENTORY OF ROADWAYS LOCATED IN FAULT ZONES}

The drift $\mathrm{W}$ level 838 is located at the average depth of $780 \mathrm{~m}$. Roadway drivage was commenced in October 2013 and terminated after 11 months [20]. On 28 June 2016, an inventory of the section between 300 and $400 \mathrm{~m}$ of the working was carried out in order to determine the impact of discontinuity in the form of numerous low throw faults on the stability of the roadway in the area of their occurrence. The inventory reflects the condition of the section after around 22 months from its drivage. Due to a specific purpose of the inventory, several characteristic sections were identified, in which geological disturbances significantly influenced the deterioration of functionality of the roadway. The map in Fig. 8 shows points presenting the location of the abovementioned sections. 


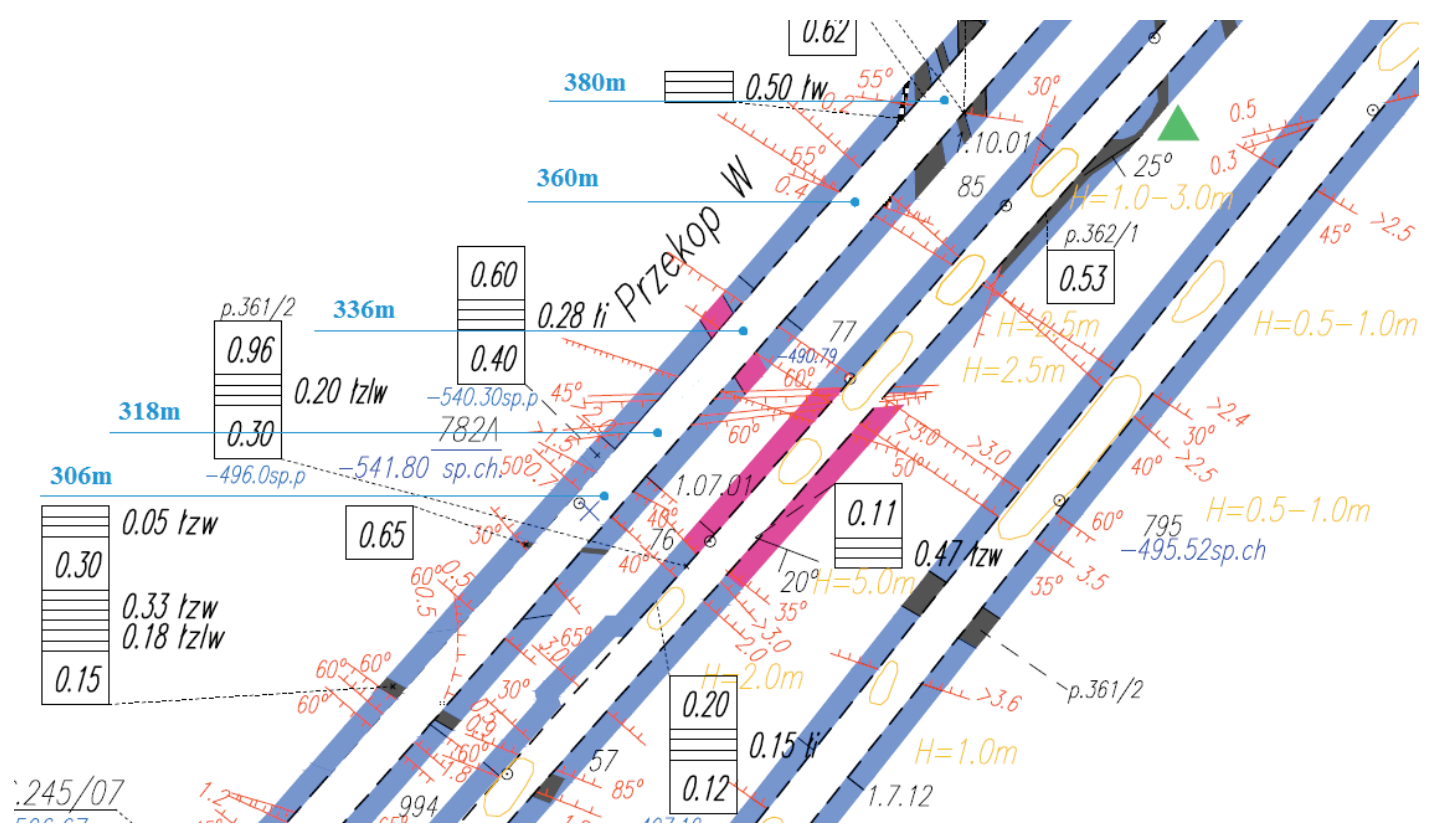

Fig. 8. The map of the analyzed section of drift W level 838

Table 5. Support details and results of measurements in drift W level 838

\begin{tabular}{|c|c|c|c|c|c|c|}
\hline \multirow{2}{*}{\multicolumn{2}{|c|}{ Description }} & \multicolumn{5}{|c|}{ Measurement bases } \\
\hline & & $306^{*}-310 \mathrm{~m}$ & $318-324 \mathrm{~m}$ & $330-336 \mathrm{~m}$ & $336-340 \mathrm{~m}$ & $360 \mathrm{~m}$ \\
\hline \multirow{6}{*}{ 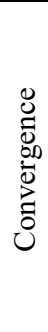 } & $\begin{array}{l}\text { Height } \\
W[\mathrm{~cm}]\end{array}$ & - & 272 & 303 & 377 & 316 \\
\hline & $\Delta W_{w}[\mathrm{~cm}]$ & - & 150.5 & 119.5 & 45.5 & 106.5 \\
\hline & $\Delta W_{w}[\%]$ & - & 35.6 & 28.3 & 10.8 & 25.2 \\
\hline & $\begin{array}{c}\text { Width } \\
S[\mathrm{~cm}]^{* *}\end{array}$ & - & 436 & 520 & 515 & 523 \\
\hline & $\Delta S_{w}[\mathrm{~cm}]$ & - & 84 & 0 & 5 & 0 \\
\hline & $\Delta S_{w}[\%]$ & - & 16.2 & 0.0 & 1.0 & 0.0 \\
\hline \multicolumn{2}{|c|}{ Support type } & ŁPC Bor $12 / \mathrm{V} 32 / 4$ & ŁPC Bor $12 / \mathrm{V} 32 / 4$ & ŁPC Bor $12 / \mathrm{V} 32 / 4$ & ŁPC Bor 12/V32/4 & ŁPC Bor $12 / \mathrm{V} 32 / 4$ \\
\hline \multicolumn{2}{|c|}{ Spacing $[\mathrm{m}]$} & 0.8 & 0.6 & 0.6 & 0.6 & 0.6 \\
\hline \multicolumn{2}{|c|}{ Steel grade } & S480W & S480W & S550W & S550W & S550W \\
\hline \multicolumn{2}{|c|}{ Reinforcements } & $\begin{array}{c}6 \text { props SV, } 2 \text { yokes } \\
\text { SD29, }+4 \text { m steel } \\
\text { beam type V29 }\end{array}$ & $\begin{array}{c}\text { two } 4 \mathrm{~m} \text { steel } \\
\text { beams V29 type }\end{array}$ & $\begin{array}{c}\text { poles } \phi 40, \text { spacing } \\
0.5-0.7 \mathrm{~m}, 4,4,5 \\
\text { poles between } \\
\text { frames }\end{array}$ & $\begin{array}{c}8 \text { steel beams V32 } \\
\text { type, spacing } 0.4 \mathrm{~m}+ \\
\text { two } 4 \text { m steel beams } \\
\text { V29 type }\end{array}$ & - \\
\hline \multicolumn{2}{|r|}{ Faults } & $\begin{array}{c}h=0.7 \mathrm{~m}, 1.5 \mathrm{~m}, 2.0 \mathrm{~m} \\
\alpha=40^{\circ}-45^{\circ} ; \\
h=3.0 \mathrm{~m} 60^{\circ}\end{array}$ & $\begin{array}{c}h=3.0 \mathrm{~m} \\
\alpha=60^{\circ}\end{array}$ & $\begin{array}{c}h=3.5 \mathrm{~m} \\
\alpha=35^{\circ}\end{array}$ & $\begin{array}{c}h=>3.0 \mathrm{~m} \\
\alpha=60^{\circ}\end{array}$ & $\begin{array}{l}h=2.5 \mathrm{~m} \alpha=30^{\circ} \\
h=2.4 \mathrm{~m} \alpha=30^{\circ} \\
h=0.4 \mathrm{~m} \alpha=55^{\circ}\end{array}$ \\
\hline \multicolumn{2}{|c|}{$\begin{array}{c}\text { Workings } \\
\text { deformation }\end{array}$} & Very considerable & Very considerable & Considerable & Moderate & Considerable \\
\hline \multicolumn{2}{|c|}{$\begin{array}{c}\text { Support } \\
\text { deformation }\end{array}$} & Very considerable & Very considerable & Considerable & Considerable & Considerable \\
\hline
\end{tabular}

* No possibility of carrying out the measurements because of flooding.

** The height on the level of lower yokes at the overlapping point of rib and roof arches.

It is worth mentioning that around $200 \mathrm{~m}$, the roadway was supported by the steel yielding support ŁPCBor 12/V32/4 [20] with nominal height of $4.225 \mathrm{~m}$ and width of $6.50 \mathrm{~m}$ near the floor, with spacing of $0.8 \mathrm{~m}$, and from $314 \mathrm{~m}$ - with spacing of $0.6 \mathrm{~m}$.
Results of measurements and observations are shown in Table 5.

In the first of the above-mentioned sections, 306-310 m, where four small faults are located, roadway deformations are significant. In the roadway 
axis, six SV props connected with two SD29 yokes were installed [19]. Roof arches have visibly plasticized, which proves an intensified vertical stress influencing the roadway frame support. Due to flooding, it was impossible to perform control measurements.

From ca. $314 \mathrm{~m}$, frame support spacing has been changed from 0.8 to $0.6 \mathrm{~m}$. At $324 \mathrm{~m}$, where a single fault with a $3 \mathrm{~m}$ throw is situated, vertical convergence is as high as $150 \mathrm{~cm}$ compared to nominal support height. A significant roadway roof lowering is visible in relation to the adjacent section; roof arch deformations can also be observed. Coal is present in the roof. The shape of the roadway contour is similar to that of the flatted frame support of the LPSp type. The percentage of floor heaving does not deviate significantly from other sections; however, it is visible and it strongly influences vertical convergence.

In the 330-340 m section, there are two faults with more than $3 \mathrm{~m}$ throws [20]. On the first six meters, polling was made in order to protect the roadway from roof rock falls and to relieve the support construction. Reinforcements were prepared regularly, on every second or third frame, using steel poles with $40 \mathrm{~mm}$ diameters: $4,4,5$ poles, respectively, secured between following roofs of the adjacent to support frames, and fixed to the roadway roof. The spacing of the poles was, on average, $0.5-0.7 \mathrm{~m}$. Problems with the roof maintenance are clearly visible: numerous torn of steel mesh both in the roof and ribs, caused by the rock mass body being forced out into the roadway, especially in places in which weaker rock strata are present, e.g., coal.

Due to serious problems with maintaining roadway dimensions, in the $336-340 \mathrm{~m}$ sections, support frames have been reinforced by securing every second or third roof arch using eight steel beams (profile V-32) with a mutual spacing of $0.4 \mathrm{~m}$. Moreover, to ensure better cooperation between the frames, the majority of steel beams were attached to the roof bar using yokes and bent bolts. Additional reinforcement has been installed in the 335-342 section: two 4-meter steel beams (V-29 profile) that have been deformed. In this section, there is a fault with a throw exceeding $3.0 \mathrm{~m}$ and a lean of $60^{\circ}$. Reinforcements installed at 336-340 m resulted in maintaining roadway height that exceeded that of the 330-336 m section by $0.7 \mathrm{~m}$. In the abovementioned section, deformations of steel mesh were less often observed. It is also significant that, due to problems with maintaining the roadway stability, installation of a profile made of the best steel now available on the market - S550W - became necessary. It was installed at $333 \mathrm{~m}$, and the spacing and frame support doors remained unchanged [20].
In the 350-365 m section, no frame support reinforcements were installed. An uneven work of frame support arches is visible, as well as the fact that they are flattened on the right side. Floor heaving increases from the left side of the roadway to the right. Coal is present in the ribs. At $360 \mathrm{~m}$, a control measurement of frame support dimensions in the roadway axis has been performed. Roadway height is $3.16 \mathrm{~m}$ $(\Delta h=106.5 \mathrm{~cm})$. Meanwhile, roadway width is $5.23 \mathrm{~m}$ $(\Delta S=87.0 \mathrm{~cm})$ at the height of lower yokes at the overlapping point of rib and roof arches; it was caused by frame door flattening. Floor heaving in this section greatly influences vertical convergence. Two faults are present in this section: one with $30^{\circ}$ dip and $2.5 \mathrm{~m}$ and $2.4 \mathrm{~m}$ throw, and the other with $55^{\circ}$ dip and $0.4 \mathrm{~m}$ throw (Table 5).

In the 380-390 m section, significant deformations in the roadway frame support are visible. $\mathrm{Nu}-$ merous welded meshes have been torn; frame support arches and stretchers stabilizing support frames have plasticized. In this section, a pinch-out of the $361 / 1$ seam occurs, preceded by a fault with a $0.4 \mathrm{~m}$ throw. Deformations in this section occur irregularly. From $400 \mathrm{~m}$ onward, roadway stability improves significantly.

\section{CONCLUSIONS}

On the basis of long-term measurements of convergence in the D-2 maingate, a deterioration of the roadway functionality has been observed, mainly influenced by vertical convergence. Floor heaving constitutes ca. $90 \%$ of vertical convergence both for roadway sections located in the impact zones of low throw faults and for sections free of the influence of additional factors. In the section where a $0.7 \mathrm{~m}$ throw occurs, vertical convergence of the roadway is $30 \%$ higher than in the case of roadway free of the influence of other factors. In the roadway section located within the fault impact zone, vertical convergence increases rapidly, up to 4 times the value measured in the section free of additional influences.

In the roadway located in waste rock area - drift W level 838 - roadway deformations indicate significant floor heaving and serious frame support deformations. In the sections with pinched-out coal in the ribs and the roof of the roadway, deformations are more extensive than in sections free of such disturbances. Reinforcements installed in those sections are sometimes insufficient to effectively prevent steel yielding support deformations, and low throw faults 
may cause local, significant deterioration of the roadway functionality.

A critical factor influencing relocation is the stress condition in the rock mass. In the "Borynia" section of the mine complex "Borynia-Jastrzębie-Zofiówka", significant relocation of ribs to the working space is observed as a result of increasing horizontal stress. Unfortunately, stress conditions have not been studied until recently. Heavy horizontal stress in the discontinuity zone intensifies deformations in roadway rocks, especially in weaker, more deformable rocks, with smooth cracking surfaces (e.g., coal). It results in easy slippage on the fault surfaces, causes rocks to become dilatant, and creates larger destruction zones in the vicinity of the roadway compared to roadway sections surrounded by harder rocks. In fault zones, cross section convergence may reach as much as $50 \%$.

For better understanding of the impact of fault zones on roadway stability, roadway sections with faults should be subject to further study and research.

\section{REFERENCES}

[1] BuKowsKa M., ĆMIEL S., Charakterystyka zmian właściwości skat karbońskich $w$ strefach tektoniki nieciagtej w Górnośląskim Zagłębiu Węlowym, Górnictwo i Geoinżynieria, Zeszyt 2, 2011, 111-119, (in Polish).

[2] Gao J., Liu H.Y., Zhang M., Aziz M.M.A., Failure process and support method of roadways excavated in inclined rock mass strata, Civil Engineering and Architecture, 2014, No. 2, 304-312.

[3] GoDYŃ K., Charakterystyka węgla kamiennego wystepujacego w strefach przyuskokowych, Przegląd Górniczy, 2013, No. 4, 45-53, (in Polish).

[4] Hongwei W., Yaodong J., Sheng X., Lingtao M., Zhinan L., Daixin D., DengQiang Z., Influence of fault slip on mininginduced pressure and optimization of roadway support design in fault-influenced zone, Journal of Rock Mechanics and Geotechnical Engineering, 2016, Vol. 8, 660-671.

[5] Kidybiński A., Podstawy geotechniki kopalnianej, Wydawnictwo Śląsk, Katowice 1982, (in Polish).

[6] MaŁkowski P., Niedbalski Z., Majcherczyk T., Investigations of hard coal mine roadways stability in stratified rock, 8th International Symposium on Ground Support in Mining and Underground Construction, 12-14.09.2016, Luleå: E. Nordlund, T.H. Jones, A. Eitzenberger (eds.), 2016, 1-13.

[7] MaŁkowski P., MajcherczyK T., Niedbalski Z., Multi-criterion Analysis of Factors Affecting Maintenance of Roadways, AGH Journal of Mining and Geoengineering, 2012, No. 1, 243-252.
[8] MaŁkowski P., Niedbalski Z., Majcherczyk T., Roadway design efficiency indices for hard coal mines, Acta Geodynamica et Geomaterialia, 2016, No. 2, 201-211. DOI: 10.13168/AGG.2016.0002.

[9] NIEĆ M., Geologia kopalniana, Wydawnictwo Geologiczne, Warszawa 1990, (in Polish).

[10] Niedbalski Z., MaŁkowski P., Majcherczyk T., Monitoring of stand-and-roof-bolting support: design optimization, Acta Geodynamica et Geomaterialia, 2013, Vol. 10, No. 2, 215-226. DOI: 10.13168/AGG.2013.0022.

[11] Onargan T., Kucuk K., Deliormanli A., Saydam S., KocA M.Y., Ground control for underground Evaporite Mine in Turkey, [in:] T. Onargan (ed.), Earth and Planetary Sciences "Mining Methods", Chapter 3, 2012, 33-46. DOI: $10.5772 / 39174$.

[12] Ostrowski Ł., MaŁKOWSKI P., Wplyw zawodnienia na wypiętrzanie skat spagowych wyrobiska korytarzowego, Przegląd Górniczy, 2016, No. 3, 28-38, (in Polish).

[13] PRUSEK S., Changes in cross-sectional area of gateroads in longwalls with roof caving, ventilated with " $U$ " and " $Y$ " systems, Archives of Mining Sciences, 2015, Vol. 60, 549-564.

[14] PRUSEK S., Empirical-statistical model of gateroads deformation, Archives of Mining Sciences, 2010, Vol. 55, 295-312.

[15] Prusek S., Bock S., Assessment of rock mass stresses and deformations around mine workings based on threedimensional numerical modeling, Archives of Mining Sciences, 2008, Vol. 53, 349-360.

[16] Shen H.C., Cheng Y.F., WANG J.Y., Finite element study on the effects of faults on the ground stress field, Petroleum Geology and Oilfield Development in Daqing, 2007, No. 4, 34-37.

[17] Sheng-Qi Y., Miao C., Hong-Wen J., Kun-Fu C., Bo M., A case study on large deformation failure mechanism of deep soft rock roadway in Xin'An coal mine, China, Engineering Geology, Vol. 217, 89-101. Retrieved on 28 December 2016, http:// www.sciencedirect.com/science/article/pii/S0013795216308614.

[18] Shuai Y., Jianbiao B., Wenfeng L., Jigang C., Lei L., Deformation mechanism and stability control of roadway along a fault subjected to mining, International Journal of Mining Science and Technology, 2012, Vol. 22, 559-565.

[19] Technical documentation of roadway D-2. „Borynia-Zofiówka-Jastrzębie" Coal mine, (unpublished).

[20] Technical documentation of drift W level 838. „Borynia-Zofiówka-Jastrzębie" Coal mine, (unpublished).

[21] Uproszczone zasady doboru obudowy odrzwiowej wyrobisk korytarzowych $w$ zaktadach wydobywajacych węgiel kamienny. (2001). Seria: Instrukcje nr 15, Katowice: Główny Instytut Górnictwa, 2001, (in Polish).

[22] Yao Q., Li X., PAn F., Wang T., WANG G., Deformation and Failure Mechanism of Roadway Sensitive to Stress Disturbance and Its Zonal Support Technology, Shock and Vibraton, 2016, Vol. 6, 1-14, DOI: 10.1155/2016/1812768.

[23] Zasady projektowania i doboru obudowy wyrobisk korytarzowych $w$ zakładach wydobywajacych węgiel kamienny. Wydanie II - poprawione, Politechnika Śląska, Instytut Eksploatacji Złóż, Gliwice 2000, (in Polish). 